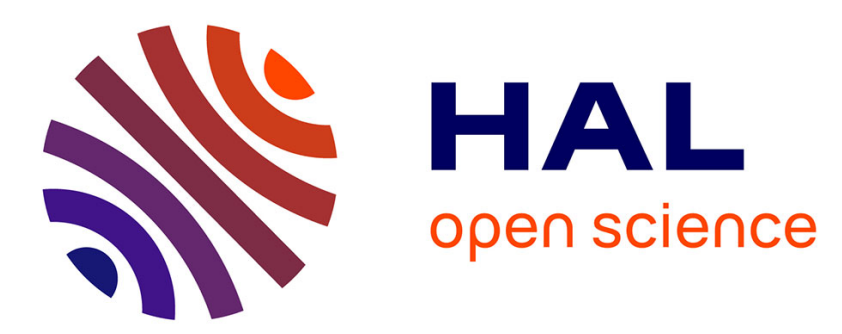

\title{
HREM Characterization of Interfaces in Thin MOCVD Superconducting Films
}

Dominique Dorignac, Sylvie Schamm-Chardon, Ch. Grigis, J. Santiso, G. Garcia, A. Figueras

\section{- To cite this version:}

Dominique Dorignac, Sylvie Schamm-Chardon, Ch. Grigis, J. Santiso, G. Garcia, et al.. HREM Characterization of Interfaces in Thin MOCVD Superconducting Films. Journal de Physique IV Proceedings, 1995, 05 (C5), pp.C5-927-C5-934. 10.1051/jphyscol:19955110 . jpa-00253779

\section{HAL Id: jpa-00253779 https://hal.science/jpa-00253779}

Submitted on 1 Jan 1995

HAL is a multi-disciplinary open access archive for the deposit and dissemination of scientific research documents, whether they are published or not. The documents may come from teaching and research institutions in France or abroad, or from public or private research centers.
L'archive ouverte pluridisciplinaire HAL, est destinée au dépôt et à la diffusion de documents scientifiques de niveau recherche, publiés ou non, émanant des établissements d'enseignement et de recherche français ou étrangers, des laboratoires publics ou privés. 


\title{
HREM Characterization of Interfaces in Thin MOCVD Superconducting Films
}

\author{
D. Dorignac, S. Schamm, Ch. Grigis, J. Santiso*, G. Garcia** and A. Figueras* \\ CNRS/CEMES-LOE, MEA, BP. 4347, 31055 Toulouse, France \\ * CSIC/ICMAB, Campus UAB, 08193 Bellaterra, Spain \\ ** S.E. CARBUROS METALICOS, Pg Zona Franca 14, 08038 Barcelona, Spain
}

\begin{abstract}
This paper is concerned with high-T $T_{c}$ superconducting compounds produced by metal-organic chemical vapour deposition. The nanostructure of different types of interfaces yttria stabilized zirconia buffer / (1-102)-sapphire substrate, $\mathrm{YBa}_{2} \mathrm{Cu}_{3} \mathrm{O}_{7-\mathrm{x}}$ film / $\mathrm{Y}_{2} \mathrm{O}_{3}$ precipitates as well as $\mathrm{YBa}_{2} \mathrm{Cu}_{3} \mathrm{O}_{7-\mathrm{x}}$ film / (001)- $\mathrm{NdGaO}_{3},-\mathrm{SrTiO}_{3}$, and - $\mathrm{MgO}$ substrates - has been investigated by high resolution electron microscopy. The orientation relationships and the corresponding layer sequences across the interfaces have been determined with the aid of computer simulations.
\end{abstract}

\section{INTRODUCTION}

Since the discovery nearly ten years ago of superconductivity in ceramic cuprates the electrical performances of these high- $T_{c}$ superconductors are known to be closely related to their crystalline structure. In particular, interfacial structure is known to be of fundamental importance in influencing the transport properties of the resulting compounds. Establishing the layer sequence across the interfaces can thus be especially useful for the preparation of extremely thin films (down to one-unit-cell thick), either as single films or as components of multilayered films [1].

High resolution electron microscopy (HREM) has already proved invaluable in understanding such interfacial structures for compounds prepared by co-evaporation [2], pulsed laser deposition [3, 5, 6, 9], thermal evaporation $[8,9]$, sputtering $[7,8,9]$ and laser ablation $[4,8,9]$.

We report here comparative results for compounds prepared by metal-organic chemical vapour deposition (MOCVD), with a view to elucidate the local atomic arrangements across various interfaces (i) yttria stabilized zirconia (YSZ) buffer / (01-12)-sapphire $\left(\mathrm{Al}_{2} \mathrm{O}_{3}\right)$ substrate, (ii) $\mathrm{YBa}_{2} \mathrm{Cu}_{3} \mathrm{O}_{7-\mathrm{x}}$ (YBCO) film / $\mathrm{Y}_{2} \mathrm{O}_{3}$ precipitates and (iii) $\mathrm{YBCO}$ films / (001)-NdGaO,$-\mathrm{SrTiO}_{3}$ or $-\mathrm{MgO}$ substrates.

\section{EXPERIMENTAL AND COMPUTATIONAL CONSIDERATIONS}

Thin films were grown epitaxially by thermal activated MOCVD reactor from organometallic precursors. $\mathrm{Zr}$ (thd $)_{4}$ and $\mathrm{Y}(\text { thd })_{3}$ complexes and $\mathrm{Y}(\text { thd })_{3}, \mathrm{Ba}(\text { thd })_{2}$ and $\mathrm{Cu}(\text { thd })_{2}$ complexes were used for $\mathrm{YSZ}$ and YBCO depositions, respectively. The deposition temperatures were around 1073K $[11,12]$.

Suitable HREM cross-section and plane-view specimens were then carefully prepared from the above films by mechanical polishing and $\mathrm{Ar}^{+}$ion milling with liquid nitrogen cooling. This now standard specimen preparation technique provided sufficiently large and thin areas (less than $10 \mathrm{~nm}$ ) to check the film quality.

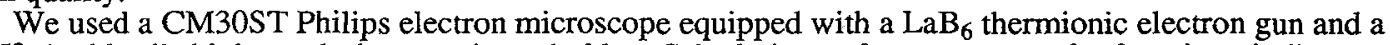
$\pm 25^{\circ}$ double-tilt high-resolution specimen holder. Calculations of contrast transfer functions indicate a first zero value of $0.2 \mathrm{~nm}$ at Scherzer defocus, which has been confirmed by numerical Fourier analysis of the experimental pictures, via the SysTEM software. The operating conditions were beam voltage $300 \mathrm{kV}$, axial-illumination bright-field operation, no objective aperture and calibrated magnification $1.02 \mathrm{M}$. The simulated images were computed using the MacTempas-CrystalKit suite of multi-slice programs, with spherical aberration $1.2 \mathrm{~mm}$, rms focal spread $8 \mathrm{~nm}$, beam divergence semi-angle $1.2 \mathrm{mrad}$, rms vibration parameter $0.02 \mathrm{~nm}$ and effective aperture $10 \mathrm{~nm}^{-1}$. 


\section{RESULTS AND DISCUSSION}

\subsection{YSZ buffer / (1-102)- $\mathrm{Al}_{2} \mathrm{O}_{3}$ substrate}

YSZ buffer layers recently proved to be effective diffusion barriers for YBCO deposition on sapphire substrates [13]. Our observed cross-sections showed nice sharp interfaces, free of any secondary phases but always presenting many atomic steps.

Figure 1 gives two examples of corresponding atomic structure images. The epitaxial relationships are found to be [-2021] $\mathrm{Al}_{2} \mathrm{O}_{3} / /$ [110] YSZ and (1-102) $\mathrm{Al}_{2} \mathrm{O}_{3} / /(001) \mathrm{YSZ}$. However an angle close to $3^{\circ}$ can be measured between the (001) YSZ and the (1-102) $\mathrm{Al}_{2} \mathrm{O}_{3}$ atomic planes (a slightly different value, $4^{\circ}$, has also been reported by $\left.\mathrm{Wu}[5]\right)$. This apparently results from a compromise between the $94.01^{\circ}$ angle appearing in the projected sapphire structure and the [001] growth direction for the YSZ crystal, which is required for optimum lattice matching $\left(\mathrm{d}_{0-11-2} \mathrm{Al}_{2} \mathrm{O}_{3}=0.348 \mathrm{~nm}, \mathrm{~d}_{110} \mathrm{YSZ}=0.359 \mathrm{~nm}\right.$ $: 3.16 \%$ resulting misfit relative to the substrate). Extra-lattice oblique planes, in agreement with the fact that $8 \mathrm{xd}_{-101-4} \mathrm{Al}_{2} \mathrm{O}_{3} \approx 7 \mathrm{xd}_{111} \mathrm{YSZ}\left(\mathrm{d}_{-101-4} \mathrm{Al}_{2} \mathrm{O}_{3}=0.255 \mathrm{~nm}, \mathrm{~d}_{111} \mathrm{YSZ}=0.293 \mathrm{~nm}\right)$, are clear. From the computer simulated images the blurred regions corresponding to the atomic steps are difficult to interpret, however the layer sequence across the interface in flat regions can be clearly recognized.

\subsection{YBCO films / $\mathrm{Y}_{2} \mathrm{O}_{3}$ precipitates}

Cross-section and plane-view observations showed the presence of "camembert"-shaped $\mathrm{Y}_{2} \mathrm{O}_{3}$ precipitates, which are randomly dispersed in the YBCO films and lead to slightly strained and misaligned regions. Their epitaxial relationship is always found to be [110] $\mathrm{Y}_{2} \mathrm{O}_{3} / /$ [010] $\mathrm{YBCO}$ and (001) $\mathrm{Y}_{2} \mathrm{O}_{3} / /(001)$ YBCO. Such an orientation relation has also been observed in sputtered films [7] and also in pulsed laser deposited [4,10] or plasma-enhanced MOCVD films [14].

\subsubsection{Cross-sections}

In this case the HREM images were recorded along the [010] YBCO direction. They revealed the rectangular projection of the precipitates, the larger dimension of which coincides with the common (001) planes [15]. This epitaxy probably occurs because of the favourable influence of the very low lattice mismatch in the interfacial $(001)$ plane $\left(\mathrm{d}_{440} \mathrm{Y}_{2} \mathrm{O}_{3}=0.375 \mathrm{~nm}, \mathrm{~d}_{100} \mathrm{YBCO}=0.383 \mathrm{~nm}: 2.09 \%\right.$ resulting misfit relative to the film). Figure 2 shows two atomic structure images of a typical interface for a nanoprecipitate with a size of about $(4 \times 30) \mathrm{nm}^{2}$. They correspond to different defocus values $(\Delta \mathrm{z})$, which produce high-contrast easily-recognizable images. It is clear that the (001) interfaces are flat, with no interfacial steps, and that crystallinity continues up to the interfaces. The image computations demonstrate that the $(001) \mathrm{Y}_{2} \mathrm{O}_{3}$ interfacial facets are exactly located in the $\mathrm{Y}$ layers of the matrix, the layer sequence across the interface being : (bulk $\mathrm{YBCO}$ )- $\mathrm{BaO}^{-\mathrm{CuO}} \mathrm{2}_{2}^{--} \mathrm{Y}-\mathrm{O}-\left(\right.$ bulk $\mathrm{Y}_{2} \mathrm{O}_{3}$ ). Along the [001] axis the lattice matching is poor $\left(\mathrm{d}_{004} \mathrm{Y}_{2} \mathrm{O}_{3}=0.265 \mathrm{~nm},<\mathrm{d}_{004}>\mathrm{YBCO}=0.293 \mathrm{~nm}: 9.6 \%\right.$ resulting misfit relative to the film). Nevertheless, since $9 \mathrm{xd}_{004} \mathrm{Y}_{2} \mathrm{O}_{3} \approx 2 \mathrm{x}<\mathrm{d}_{004}>\mathrm{YBCO}$, local correspondences and some coincidences between the metallic layers in the matrix and the (004) planes in the precipitates can be interpreted consistently.

\subsubsection{Plane-views}

In this case the HREM images were recorded along the [001] YBCO direction. They revealed the discshaped projection of the precipitates. An example of the corresponding interface for a large disc (of about $100 \mathrm{~nm}$ diameter) is shown figure 3 . It is clear that the $(010) \mathrm{Y}_{2} \mathrm{O}_{3}$ atomic planes are nearly coherent with the (1-10) YBCO ones, except in particular sites where the low mismatch $\left(d_{400} \mathrm{Y}_{2} \mathrm{O}_{3}=0.265 \mathrm{~nm}, \mathrm{~d}_{220}\right.$ YBCO $=0.273 \mathrm{~nm}: 2.9 \%$ resulting misfit relative to the film) is accommodated by (010) extra lattice planes in the precipitate, in very good agreement with the interplanar distance ratio $\left(34 \mathrm{xd}_{400} \mathrm{Y}_{2} \mathrm{O}_{3} \approx\right.$ $\left.33 \mathrm{xd}_{220} \mathrm{YBCO}\right)$.

\subsection{YBCO films / (001)- $\mathrm{NdGaO}_{3},-\mathrm{SrTiO}_{3}$, and -MgO substrates}

In this part we review our results concerning the interfaces between thin superconducting YBCO films and three particular substrates currently used for growing these films. We shall examine them, in turn, in order of increasing lattice mismatch.

\subsection{1. $\mathrm{NdGaO}_{3}$ as substrate}

HREM performed on these interfaces always showed very flat interfaces, without any amorphous phases. However, we often observed stacking defects close to the interface, but we never saw interface phases of composition $\mathrm{YBaCu}_{2} \mathrm{O}_{5}$, as reported by Zandbergen et al. [9]. Far from the interface we also observed 
the presence of other crystalline phases related to the standard "1:2:3" YBCO structure.

As a typical example, figure 4 shows two cross-sectional views of the same region imaged with slightly different experimental conditions : from left to right, the microscope defocus and specimen tilt varied and the specimen damage increased. The simulations indicate that the first picture corresponds to a thickness of $6 \mathrm{~nm}$ and a defocus of $-40 \mathrm{~nm}$ (cations black). The relative orientations of the crystals are found to be : [100] $\mathrm{NdGaO}_{3} / /$ [110] $\mathrm{YBCO}$ and (001) $\mathrm{NdGaO}_{3} / /(001) \mathrm{YBCO}$. The very good match between the two lattices is clear $\left(\mathrm{d}_{020} \mathrm{NdGaO}_{3}=0.275 \mathrm{~nm}, \mathrm{~d}_{110}\right.$ YBCO $=0.273 \mathrm{~nm}: 0.7 \%$ resulting misfit relative to the substrate, i.e. $136 \mathrm{xd}_{020} \mathrm{NdGaO}_{3} \approx 137 \mathrm{xd}_{110} \mathrm{YBCO}$ ). Moreover, the layer sequence across the interface appears to be either (bulk $\mathrm{NdGaO}$ )- $\mathrm{NdO}-\mathrm{GaO}_{2}--\mathrm{Y}-\mathrm{CuO}_{2}$-(bulk $\mathrm{YBCO}$ ) or (bulk $\mathrm{NdGaO}_{3}$ )- $\mathrm{GaO}_{2}-\mathrm{NdO}-\mathrm{CuO}_{2}-\mathrm{Y}$-(bulk YBCO). However, the first seems more probable since the width of the dark line located on the left of the marked $\mathrm{Y}$ row is larger than those corresponding to the $\mathrm{CuO}_{2}$ rows in the bulk YBCO and quite similar to those corresponding to the $\mathrm{GaO}_{2}$ rows in the bulk $\mathrm{NdGaO}_{3}$.

Figure 4 also shows a stacking defect in the second YBCO layer after the interface, marked by a black-white arrow. It too reveals the presence in the matrix of two periods larger than usual (arrowed). They could correspond to the "2:5:7" phase even if it appears that the match of the simulation with the experimental image is still rather qualitative. The "2:5:7" unit cell consists' of two "1:2:3" unit cells together with one $(\mathrm{BaO}-\mathrm{CuO})$ sequence.

\subsection{2. $\mathrm{SrTiO}_{3}$ as substrate}

Our HREM observations on $1-5 \mathrm{~nm}$ thick cross-sections have directly confirmed the layer sequence. The interfaces were imaged edge-on along [010].

Examples of high magnification images are shown in figure 5, for identical areas imaged with different microscope defoci. These pictures indicate that the orientation relations are : [010] $\mathrm{SrTiO}_{3} / /$ [010] YBCO and (001) $\mathrm{SrTiO}_{3} / /(001)$ YBCO. From both the $\mathrm{YBCO}$ and $\mathrm{SrTiO}_{3}$ image simulations (inserted in the photographs) the specimen thickness is known to be close to $3 \mathrm{~nm}$ and the defoci close to $-35 \mathrm{~nm}$ (cations black) and $-88 \mathrm{~nm}$ (cations white). Unfortunately the SrO substrate layers cannot be distinguished from the $\mathrm{TiO}_{2}$ layers, since they give rise to quite similar contrasts. The atomic stacking sequence is thus found be either (bulk $\left.\mathrm{SrTiO}_{3}\right)-\mathrm{SrO}-\mathrm{TiO}_{2}--\mathrm{BaO}-\mathrm{CuO}_{2}$-(bulk $\mathrm{YBCO}$ ) or (bulk $\mathrm{SrTiO}_{3}$ )$\mathrm{TiO}_{2}-\mathrm{SrO}--\mathrm{BaO}-\mathrm{CuO}_{2}$-(bulk YBCO). However, as already suggested by Ramesh et al. [6] and also Wen et al. [8], it seems reasonable to think that the first possibility is more probable than the second one, since in this case the alternance of small cation $\left(\mathrm{TiO}_{2}, \mathrm{CuO} / \mathrm{CuO}_{2}\right)$ layers and large cation $(\mathrm{SrO}, \mathrm{BaO} / \mathrm{Y})$ layers will normally continue across the interface.

It can also be noted that the lattice mismatch, which is good enough $\left(d_{200} \mathrm{SrTiO}_{3}=0.391 \mathrm{~nm}, \mathrm{~d}_{100}\right.$ YBCO $=0.383 \mathrm{~nm}: 2.05 \%$ resulting misfit, i.e. $48 \mathrm{xd}_{200} \mathrm{SrTiO}_{3} \approx 49 \mathrm{xd}_{100} \mathrm{YBCO}$ ), is here clearly accommodated by one defect at the end of one particular "(301)" YBCO pseudo-plane (arrowed). This supplementary pseudo-plane terminates at one $\mathrm{Cu}$ column in the $\mathrm{CuO}$ layer located one cell above the interface. When looking at a grazing angle along this pseudo-plane near the defect, an interfacial $\mathrm{SrTiO}_{3}$ unit-cell step can be easily seen, which seems to be replaced by a $(-\mathrm{CuO}-\mathrm{BaO})$ block. An analogous situation has also been observed by Shimura et al. [1] and Wen et al. [8].

\subsection{3. $\mathrm{MgO}$ as substrate}

These interfaces were always viewed along the common [100] direction. We especially concentrate our investigations on clean and flat interfaces, for which strain dark-contrast zones and a regular dislocation array along the interface are clearly visible, as reported earlier $[2,3]$. The orientation relationships were found to be : [100] MgO // [100] YBCO and (001) MgO // (001) YBCO, in agreement with previous observations $[2,3,9]$. Another orientation, [100] MgO // [110] YBCO, has also been reported [3].

Figure 6 shows cross-sectional images for two different microscope defocus values. From the simulations, the thickness is close to $3 \mathrm{~nm}$ and the defoci are $-35 \mathrm{~nm}$ (cations black) and $-85 \mathrm{~nm}$ (cations white). The periodic (010) extra-lattice planes in the film up to the interface, which accommodate the poor lattice mismatch $\left(\mathrm{d}_{010} \mathrm{MgO}=0.421 \mathrm{~nm}, \mathrm{~d}_{010} \mathrm{YBCO}=0.389 \mathrm{~nm}: 7.6 \%\right.$ resulting misfit, i.e. $12 \times \mathrm{d}_{010}$ $\mathrm{MgO} \approx 13 \times \mathrm{d}_{010} \mathrm{YBCO}$ ), are indicated.

The layer sequence across the interface is certainly : (bulk $\mathrm{MgO}$ )-MgO---BaO-CuO 2 -(bulk $\mathrm{YBCO}$ ). It should be noted that this first YBCO plane $(\mathrm{BaO})$ differs from the first plane found by Zandbergen et al. $(\mathrm{CuO},[9])$ and also from the one expected by Tietz et al. $\left(\mathrm{CuO}_{2},[2]\right)$.

\subsection{Concluding remarks}

This work was intended not only to give useful information for chemists and physicists involved in superconductor research, but also to illustrate the power of the high resolution electron microscopes for studying, at the atomic level, the atomic sequences across crystalline interfaces in a wide range of analogous ceramic materials. 

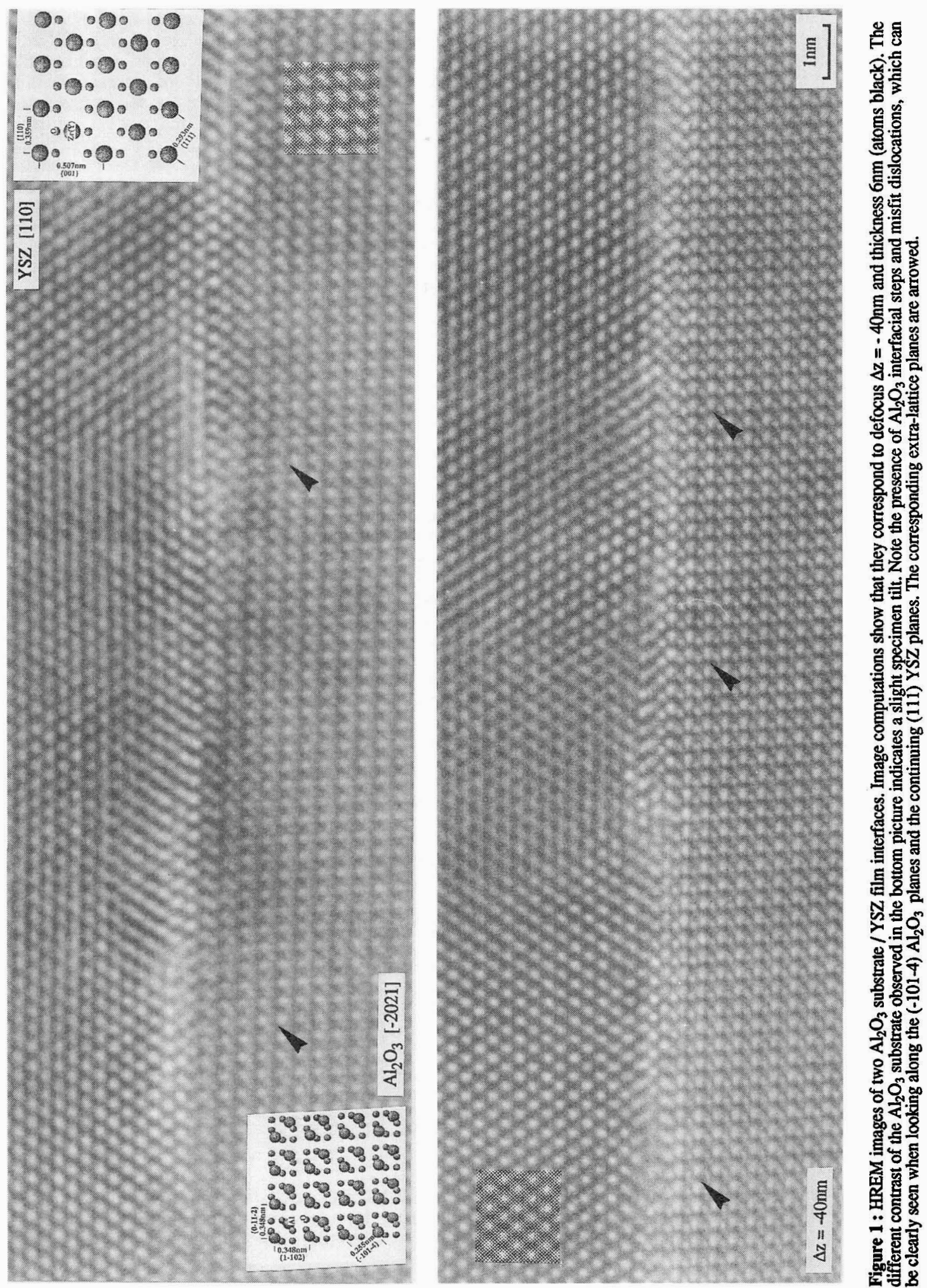
C5-931

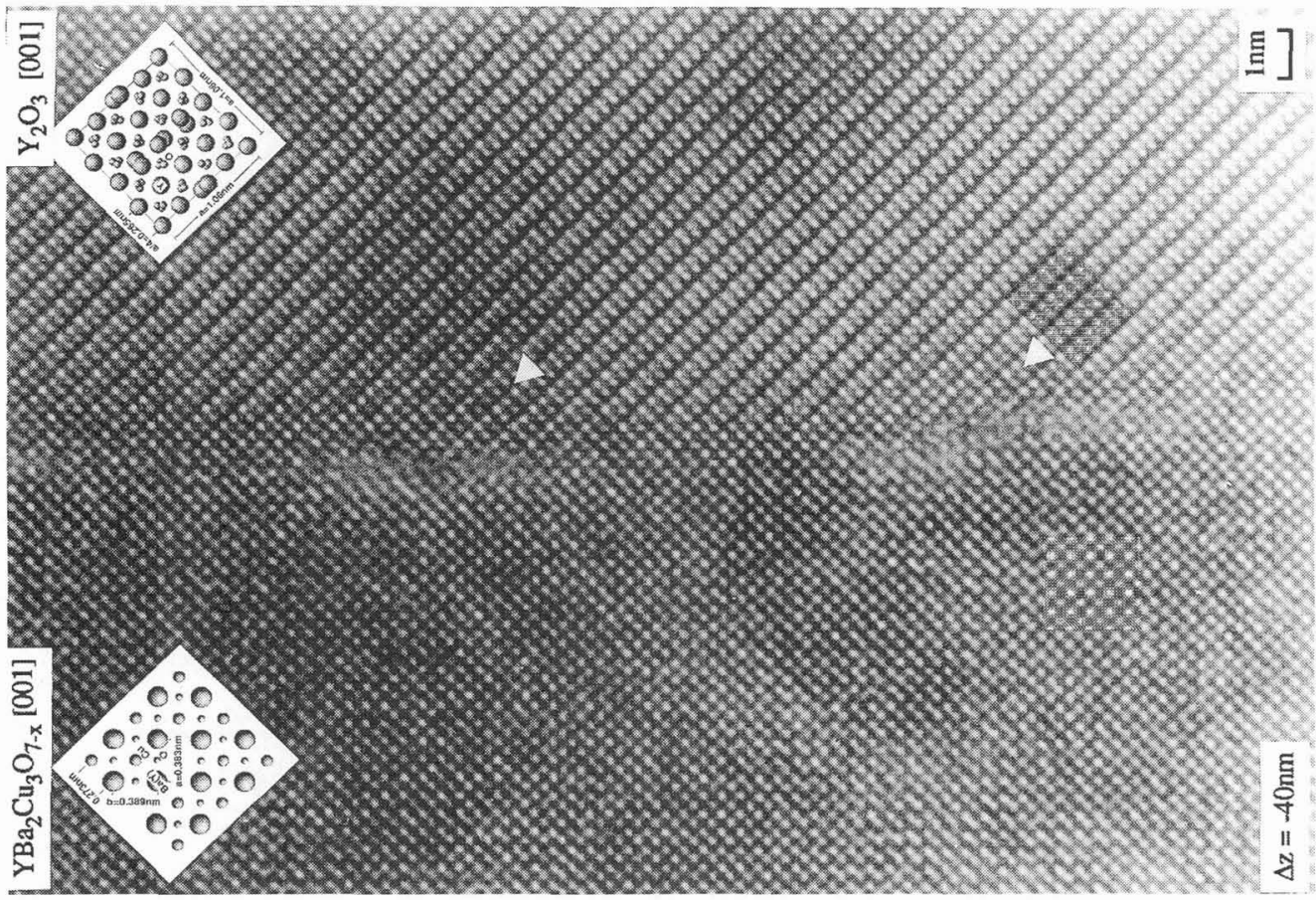

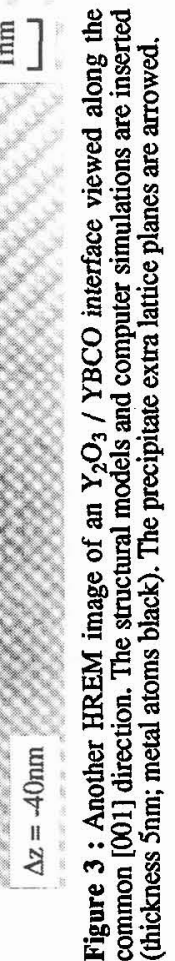

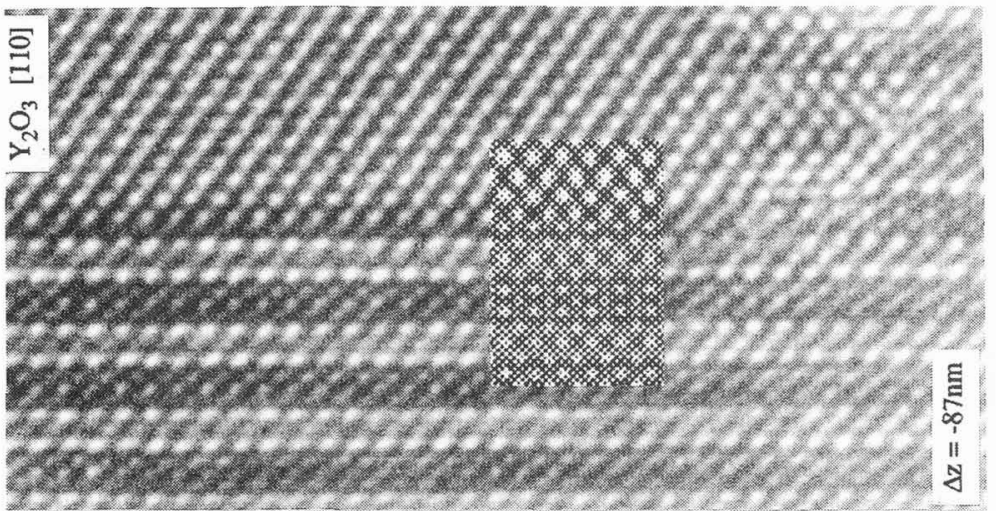

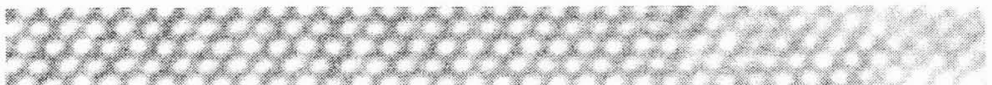

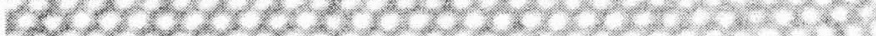

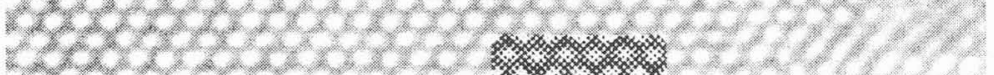

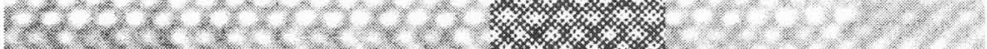

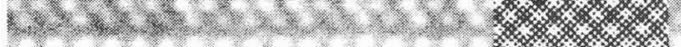

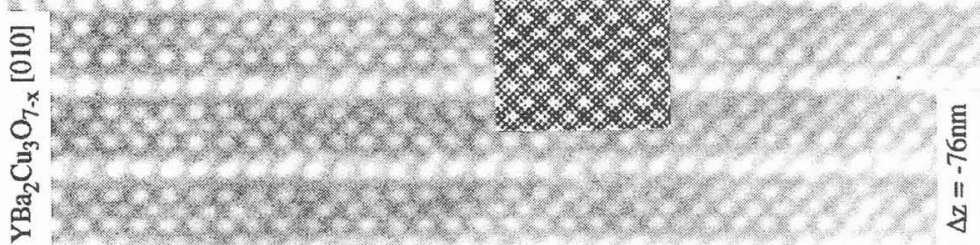

E]

\&્छ

总

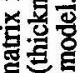

을 즌

空要

40,40

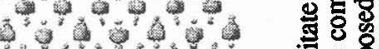

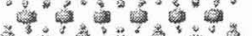

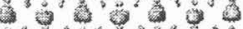

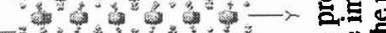

9.9.9.9

0.0.0.0.0.0

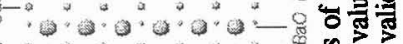

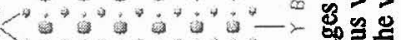

9.0.6.0.0.8 -

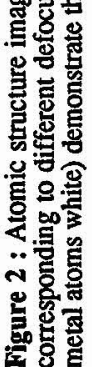




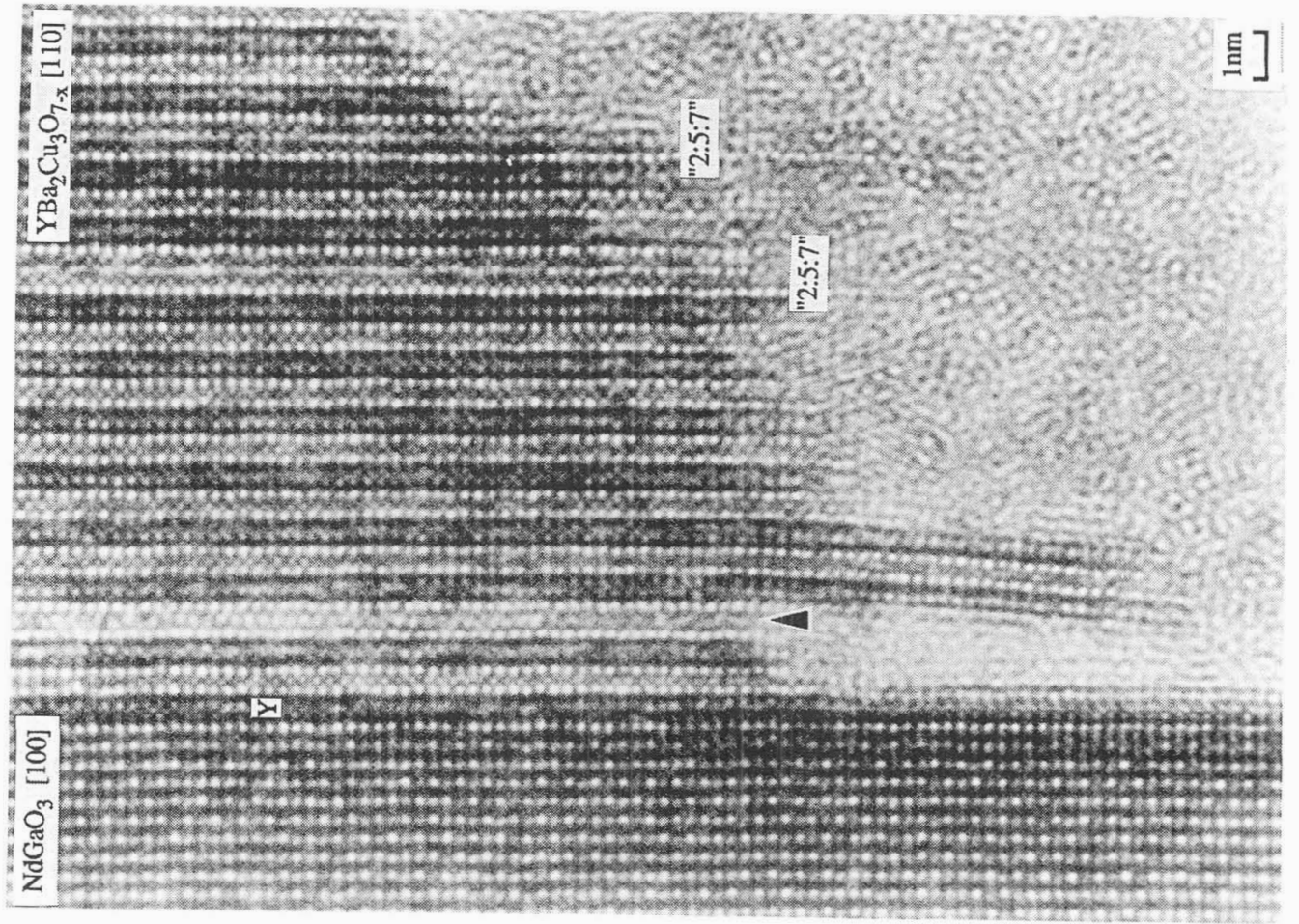



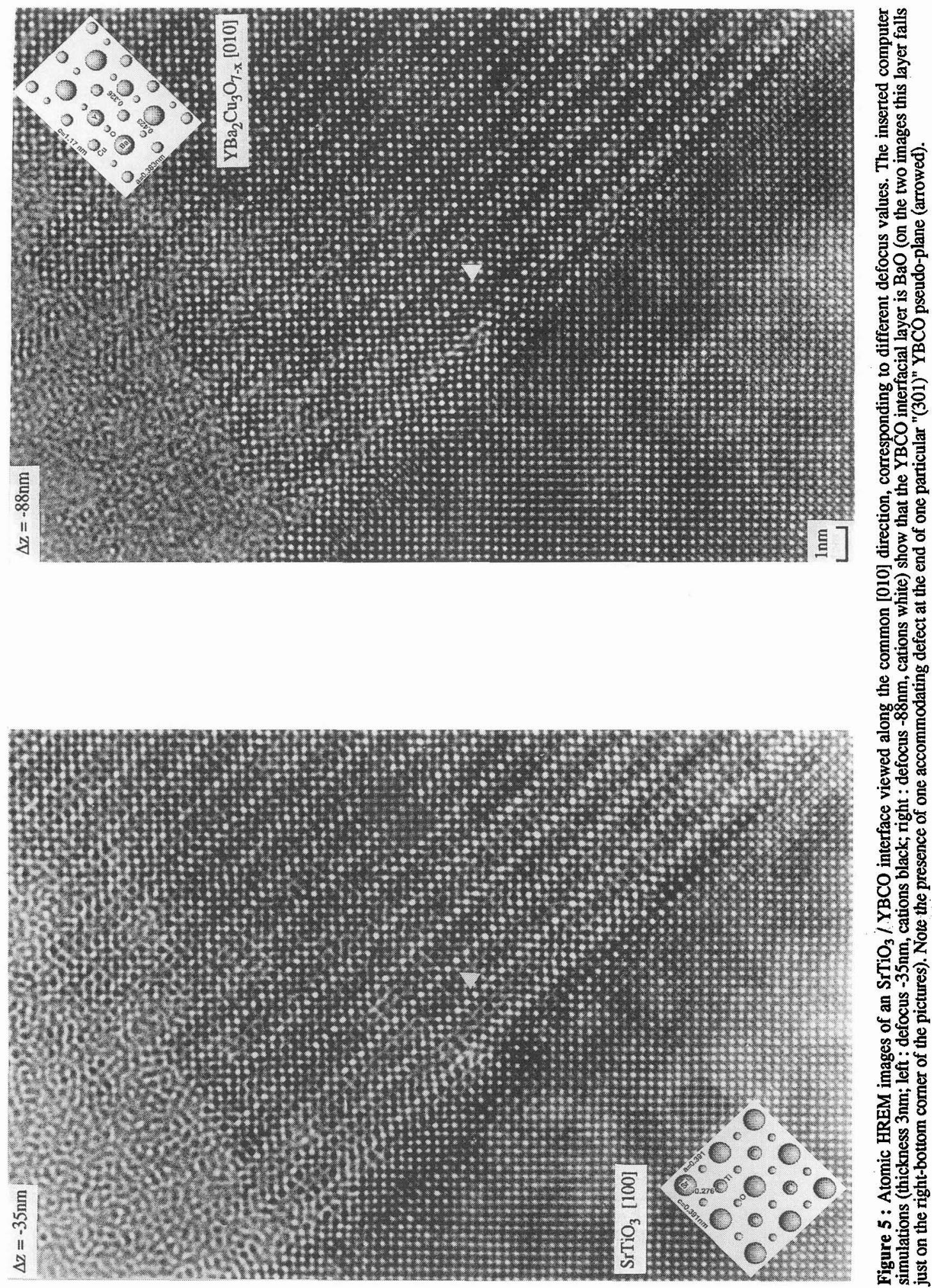

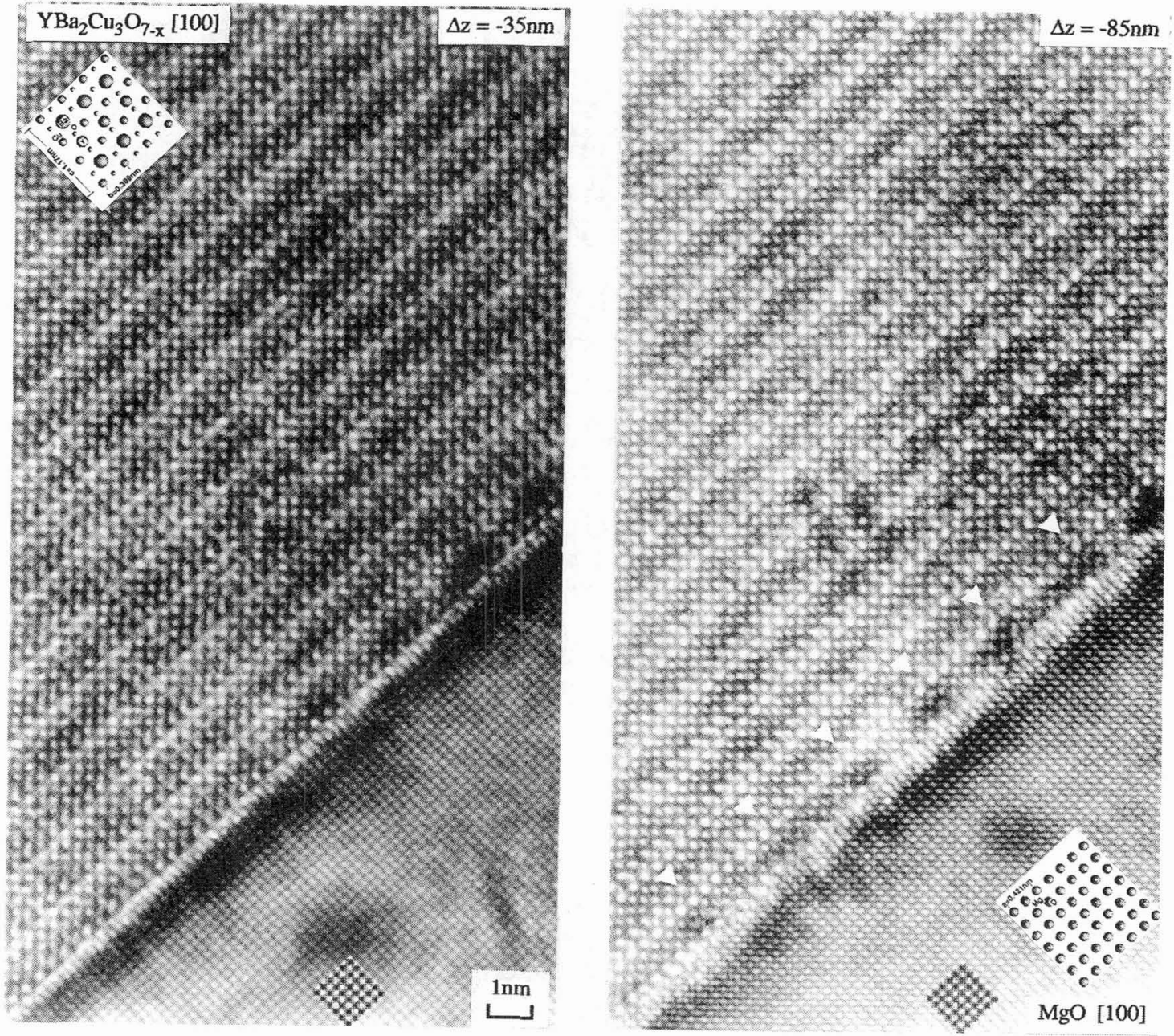

Figure 6 : HREM cross-sectional views of a MgO / YBCO interface for two different microscope defoci (very close to those used figure 5 : left, cations black ; right, cations white). As for $\mathrm{SrTiO}_{3}$, the $\mathrm{YBCO}$ interfacial layer appears to be $\mathrm{BaO}$ (exactly placed in the left-bottom comer on both pictures). The regular array of the film extra-lattice planes is indicated by arrows.

\section{References}

[1] Shimura K., Daitoh Y., Yano Y., Terashima T., Bando Y., Matsuda Y, Physica C 228 (1994) 91-102.

[2] Tietz L.A., Carter C.B., Lathrop D.K., Russek S., Buhrman A., J. Mat. Res. 4 (5) (1989) 1072-1081.

[3] Ramesh R., Hwang D., Ravi T.S., Inam A., Barner J.B., Appl. Phys. Lett. 56 (22) (1990) 2243-2245.

[4] Eibl O., Roas B., J. Mat. Res. 5 (11) (1990) 2620-2632.

[5] Wu X.D., Muenchausen R.E., Nogar N.S., Pique A., Appl. Phys. Lett. 58 (3) (1991) 304-306.

[6] Ramesh R., Inam A., Hwang D., Ravi T.S., Sands T., Xi X., J. Mat. Res. 6 (11) (1991) 2264-2271.

[7] Catana A., Broom R.F., Bednorz J.G., Mannhart J., Appl. Phys. Lett. 60 (8) (1992) 1016-1018.

[8] Wen J.G., Traeholt C., Zandbergen H.W., Joosse K., Reuvekamp E., Physica C 205 (1993) 354-362.

[9] Zandbergen H.W., Wen J.G., Traeholt C., Svetchnikov V., J. Alloys Compounds 195 (1993) 85-92.

[10] Bardal A., Eibl O., Physica C 216 (1993) 365-381.

[11] Santiso J., Figueras A., Schamm S., Grigis Ch., Dorignac D., Physica C 235-240 (1994) 619-620.

[12] Garcia G., Casado J., Llibre J., Doudkowsky M., Santiso J., Figueras A., this conference.

[13] Eibl O., Hradil K., Schmidt H. Physica C 177 (1991) 89-94.

[14] Lu P., Zhao J., Chern C.S., Li Y.Q., Kulesha G.A., Gallois B., J. Mat. Res. 7 (8) (1992) 1993-2002.

[15] Dorignac D., Schamm S., Grigis Ch., Sévely J., Santiso J., Physica C 235-240 (1994) 617-618. 
NEW METHODS AND MATERIALS 
